\title{
Association Between Allergic Diseases and Attention-Deficit/ Hyperactivity Disorder (ADHD) Symptoms in Children Aged 6-12 Years Using the Filipino Version of the Vanderbilt ADHD Parent Rating Scale
}

\author{
Glaiza M. Madulara, MD and \\ Agnes $G$. Andaya, MD
}

\section{ABSTRACT}

BACKGROUND: Over the last decades, the hypothesis that an allergic response could lead to the development of attention-deficit/hyperactivity disorder (ADHD) was raised and clinical studies investigated the co-existence of both. These studies had shown that allergic diseases and neurobehavioral disorders were concurrent and could be associated with genetic factors, neuroimmunity and microbial dysbiosis. To date, this was the first study in the Philippines to evaluate the prevalence and association of allergic diseases, its severity and ADHD symptoms.

OBJECTIVE: The objective of this study was to determine the association of allergic diseases and ADHD symptoms among children aged 6-12 years based on parental report using the Filipino version of the Vanderbilt ADHD Parent Rating Scale.

METHODS: School-aged children between 6 and 12 years with physician diagnosed allergies

$\triangle$ Glaiza Madulara

doc.glymadulara@gmail.com

Department of Pediatrics, Section of Allergy and Clinical Immunology, University of Santo Tomas, España, Manila, Philippines, 1015 (bronchial asthma, allergic rhinitis, atopic dermatitis, allergic conjunctivitis, drug allergy, food allergy and/or acute or chronic urticaria) were randomly selected. Skin prick test (SPT) to aeroallergens was done. The parents completed the Filipino version of the Vanderbilt ADHD Diagnostic Parent Rating Scale (VADPRS), a screening tool for ADHD.

RESULTS: Among the 415 patients, 135 (32.5\%) of them screened positive for ADHD symptoms. Upon assessment of the Vanderbilt parent rating subscale responses, $13.49 \%$ of the children were categorized as predominantly inattentive subtype, $6.02 \%$ as predominantly hyperactive/impulsive subtype and $13.01 \%$ as combined inattention/hyperactivity.

Three hundred and seventy six (91\%) children were diagnosed with asthma. Among these asthmatics, $119(32 \%)$ had ADHD symptoms with the following subtypes - predominantly inattentive subtype (13.56\%), predominantly hyperactive/impulsive subtype $(5.05 \%)$ and combined inattention/ hyperactivity (13.03\%). Combined inattention/ hyperactivity subtype had a significant proportion of severe asthmatics, as compared to mild or moderate asthma ( $p$ value $=0.026$ )

Furthermore, $389(94 \%)$ children were diagnosed with allergic rhinitis. Among these patients, 130 
$(33 \%)$ had ADHD symptoms with the following subtypes - predominantly inattentive subtype (13.62\%), predominantly hyperactive/impulsive subtype (6.43\%) and combined inattention/ hyperactivity (13.37\%). However, evidence was not sufficient to demonstrate an association between ADHD subtypes and allergic rhinitis severity.

Lastly, 206 (50\%) children were diagnosed with atopic dermatitis. Among these patients, 71 (34\%) had ADHD symptoms with the following subtypes - predominantly inattentive subtype (14.56\%), predominantly hyperactive/impulsive subtype $(4.85 \%)$ and combined inattention/hyperactivity (15.05\%). However, there was insufficient evidence to demonstrate a link between ADHD subtypes and atopic dermatitis severity.

CONCLUSION: Children with allergies, especially those with severe asthma, are more likely to have ADHD symptoms.

Key words: attention deficit hyperactivity disorder, allergic disease, allergic sensitization, asthma

\section{INTRODUCTION}

The increase in prevalence and burden of allergic diseases, such as asthma, allergic rhinitis and atopic dermatitis, was paralleled by a similar surge in attention deficit/hyperactivity disorder (ADHD) diagnoses. [1] Both were common chronic disorders affecting children. Immune dysregulation and inflammation were classic hallmarks in both allergic and neurodevelopmental diseases indicating a converging pathophysiology.[2] Immune responses in allergic diseases may affect the central nervous system and predispose children to neurodevelopmental disorders, including ADHD. Clinical studies revealed that allergic, neurodevelopmental and behavioral disorders were commonly concurrent and the underlying mechanisms include genetic factors, neuroimmunity and microbial dysbiosis. [2]

Over the last decades, the hypothesis that an allergic response could lead to the development of ADHD was raised.[3] Several studies reported that children with allergic diseases had a higher risk of developing ADHD, with academic and behavioral problems exhibiting as hyperactive and impulsive behaviors. [2,4-9] Early respiratory allergy symptoms and food allergy independently and synergistically contributed to an increased ADHD risk.[10] In an analysis of 19 US population-based surveys, attention deficit (AD) alone, asthma alone, and $A R$ alone were each significantly associated with $A D H D$, and the combination of $A D$ and asthma further increased ADHD risk.[11] A meta-analysis of longitudinal studies revealed an overall weighted odds ratio of 1.34 for asthma, 1.32 for atopic eczema and 1.52 for allergic rhinitis.[3] A birth cohort reported a significant association between early atopic dermatitis in the first four years of life and ADHD development by eight years of age.[12] In a large-scale cross-sectional, population-based survey of 2,772 Taiwanese children, a significant relationship between atopic dermatitis with allergen sensitization and ADHD, as well as between asthma with allergen sensitization and ADHD was reported. [8] The results of Hak and colleagues' case-control study suggested an increased risk of ADHD in boys with a history of asthma and cow's milk intolerance. [6] Suwan et al.'s study supported the hypothesized relationship between pediatric allergic sensitization, allergic rhinitis and ADHD.[1]

Contrary to these findings, other studies revealed no association between allergic diseases and ADHD behaviors.[13-16] Biederman and colleagues argued against a significant etiological and pathophysiological relationship between asthma and $A D H D$, but suggested that both were independently transmitted in families. [14] A study by Gaitens et al. did not support an association between lgE-mediated atopic responsiveness and $A D H D$, but they did not rule out an association between allergic symptoms and ADHD based on other mechanisms.[15] McGee et al. found no association between a history of allergic diseases (asthma, eczema, rhinitis and urticaria) at ages 9 to 13 years and parent, teacher and self-reports of ADHD behaviors. Furthermore, reports of ADHD behaviors were not related to the level of atopic responsiveness by skin test or serum lgE levels at the age of 13 years. [16]

Given such conflicting evidence on the association, it was suspected that a substantial proportion of children with allergic diseases may have undiagnosed ADHD. Further research is needed to understand why there appears to be an increased risk of developing ADHD in children with allergy and asthma. 
A better understanding of the relationship between allergic disease severity and the development of ADHD symptoms has public health relevance as it may lead to targeted screening, preventive measures, treatments and improved quality of life for children with allergic disease who are at an increased risk of developing ADHD. $[1,17]$

To date, this was the first local study to investigate the prevalence and association between allergic diseases, its severity and ADHD symptoms among children.

\section{Objectives}

The main objective was to determine the association of allergic diseases and ADHD symptoms among children aged 6 to 12 years old based on parental report using the Filipino version of the Vanderbilt ADHD Parent Rating Scale.

The specific objectives were to determine the prevalence of ADHD symptoms among allergic patients and determine the association of allergic diseases and its severity with ADHD symptoms.

\section{METHODOLOGY}

The study was a cross-sectional, observational, prospective study that was conducted at the University of Santo Tomas Hospital - Ambulatory Care Services (Allergy and Immunology Clinic) and Doctors' Clinics.

School children aged 6 to 12 years old with allergies (bronchial asthma, allergic rhinitis, atopic dermatitis, allergic conjunctivitis, drug allergy, food allergy and/or acute or chronic urticaria) diagnosed by physicians from the aforementioned clinics were randomly selected by systematic sampling technique.

The following were excluded in this study: parents who refused to give their informed consent to participate; parents with hospitalized or admitted children; patients with physician-diagnosed behavioral problems, such as ADHD; patients who were not cooperative with the skin prick test; patients diagnosed with seizure disorder, neuromuscular, genetic, chromosomal or congenital disorder, hearing loss, neurodevelopmental delay, speech delay, receptive language delay, cerebral palsy, learning disability, any psychiatric illness, autism spectrum disorder, mood disorder, oppositional- defiant disorder, conduct disorder, anxiety and/ or depression; and lastly, those with a family history of psychiatric illness, psychotic disorders, schizophrenia, neurodevelopmental, behavioral, cognitive disorders, autism spectrum disorder, mood, and anxiety disorders among first-, second-, and third-degree relatives.

Baseline clinical assessment and information on demographic variables were recorded. Other data obtained were: allergic comorbidities, age, gender, residential area (urban or rural), body mass index, patient history of prematurity, patient history of exclusive breastfeeding ( $\geq 6$ months), environmental exposures (industrial or automotive smoke, cigarette) tobacco smoke, animal fur, dander or feather), maternal prenatal history, number of other children at home, and $\lg E$ sensitization status via skin prick test ("monosensitized" or sensitized to only one class of allergen or "polysensitized" or sensitized to more than one class of allergen).

The Global Initiative for Asthma (GINA) 2018 guidelines was used for the diagnosis and classification of bronchial asthma based on severity. [18] Allergic Rhinitis and its Impact on Asthma (ARIA) guidelines was used for allergic rhinitis diagnosis and classification.[19] The severity of atopic dermatitis was categorized based on the National Institute for Health and Clinical Excellence (NICE) guidance.[20]

Since allergic sensitization was the most important risk for development of allergic diseases, skin prick test (SPT) to aeroallergens was performed and done at the University of Santo Tomas Hospital Allergy and Immunology Clinic and Doctors' Clinics by allergists in all patients using the diagnostic extracts to categorize as "monosensitized" or "polysensitized". Aeroallergens included were house dust, Dermatophagoides pteronyssinus, Dermatophagoides farinae, cat pelt, dog epithelium, cattle hair, horse hair, cockroach, mosquito, mixed feathers, mixed molds, Bermuda grass, Acacia, mixed molds and Candida sp. Histamine was used as positive control and saline as negative control. A positive SPT was defined as a wheal $\geq 3 \mathrm{~mm}$ greater than a negative saline control after 15 minutes, which indicates the presence of specific $\lg E$ to the allergen tested.

Since a definitive diagnosis of ADHD can only be made after a thorough clinical evaluation by a 
neurodevelopmental and behavioral specialist and upon fulfillment of the Diagnostic and Statistical Manual of Mental Disorders, Fifth Edition (DSM-5) criteria, a less complex screening tool for ADHD assessment which was the Vanderbilt ADHD Diagnostic Rating Scale (VADRS) was developed and promoted as an alternative tool for children aged 6 to 12 years old.[21,22] Permission to use the Filipino version of the VADPRS was obtained from Dr. Luisa Ysabel Diaz, the primary author of the Filipino version of the questionnaire.[23] The parents completed the Filipino version of the Vanderbilt ADHD Diagnostic Parent Rating Scale in the clinics, which contained 55 items. Directions for filling out the form required them to recall about their child's behavior for the past six months. Symptoms scales were rated on a 4-point scale: never $=0$, occasionally $=1$, often $=2$, very often $=3$. Similarly, performance scales were rated on a 5-point scale: excellent $=$ 1 , above average $=2$, average $=3$, somewhat of a problem $=4$, problematic $=5$. [24] Scores were tallied to meet the DSM criteria for diagnosis. Even though the Vanderbilt ADHD Parent Rating Scale was designed to be a self-applicable instrument, in this study, the scale was used in a one-on-one private interview with the primary investigator in anticipation that some parents have low schooling. It was explained to the participants that the Vanderbilt ADHD Diagnostic Rating Scale was a screening tool for ADHD. It was not intended as a sole source in the diagnosis of children with ADHD. Hence, if the screen was positive, a more detailed evaluation was warranted and a referral to a pediatric developmental-behavioral specialist was done.

The study protocol was approved by the University of Santo Tomas Hospital - Institutional Review Board and complied with the principles outlined in the Helsinki Declaration.

\section{STATISTICAL ANALYSIS}

Descriptive statistics was used to summarize the general and clinical characteristics of the participants. Frequency and proportion were used for nominal variables, median and range or interquartile range for ordinal, interval and ratio variables. Chi-squared test and Fisher's exact test were used to determine the difference of frequency between groups, respectively. All valid data were included in the analysis. Missing variables were neither replaced nor estimated. Null hypothesis was rejected at $0.05 \alpha$-level of significance. STATA 15.0 was used for data analysis.

\section{RESULTS}

This study recruited a total of 415 children with allergic disease. Of these atopic children, 135 (32.5\%) screened positive for ADHD symptoms (Table 1). The median age was 9 years, 229 (55.18\%) were female, $232(55.9 \%)$ live in urban residential areas, and 211 (50.84\%) were exclusively breastfed. Over half of these children had exposure to industrial/ automotive smoke (53.01\%), cigarette/tobacco smoke $(55.66 \%)$, or animal fur, dander or feather $(52.53 \%)$. A majority of the participants were polysensitized (71.81\%) to aeroallergens.

The median number of allergic comorbidities was 3 (range 1 to 6), with the top three most common allergic diseases as follows - allergic rhinitis $(93.73 \%)$, asthma $(90.6 \%)$ and atopic dermatitis (49.64\%).

Among the 415 children, 135 (32.5\%) screened positive for ADHD symptoms (Appendix A). Upon assessment of the Vanderbilt parent rating subscales responses, $13.49 \%$ of the atopic children were categorized as predominantly inattentive subtype, $6.02 \%$ as predominantly hyperactive/impulsive subtype and $13.01 \%$ as combined inattention/ hyperactivity (Table 3).

Analysis of these ADHD subtypes with severity of asthma, allergic rhinitis, atopic dermatitis and type of sensitization were shown in Tables $3.1-3.4$.

Of 415 patients with allergies, there were $376(91 \%)$ diagnosed with asthma. Among these asthmatics, 119 (32\%) had ADHD symptoms with the following subtypes - predominantly inattentive subtype $(13.56 \%)$, predominantly hyperactive/ impulsive subtype $(5.05 \%)$ and combined inattention/hyperactivity (13.03\%). There was insufficient evidence to demonstrate a difference in ADHD types with asthma severity, except for combined type which had a significantly higher proportion among severe asthmatics compared to mild or moderate ( $p$-value $=0.026$ ) (Table 3.1).

Of the 415 patients with allergies, there were 389 (94\%) diagnosed with allergic rhinitis. Among these patients, $33 \%$ had ADHD symptoms with 
Table 1. Demographic profile of children with allergies ages 6 to 12 years $(n=415)$

\begin{tabular}{ll}
\hline & $\begin{array}{l}\text { Frequency (\%); } \\
\text { Median (Range) }\end{array}$ \\
\hline ADHD symptoms & $135(32.5)$ \\
Age, years & $9(6-12)$ \\
Sex & \\
$\quad$ Male & $186(44.82)$ \\
Female & $229(55.18)$ \\
Residential area & \\
Urban & $232(55.9)$ \\
Rural & $183(44.1)$ \\
Body Mass Index & \\
Wasted & $21(5.06)$ \\
Normal & $308(74.22)$ \\
Possible risk of overweight & $27(6.51)$ \\
Overweight & $42(10.12)$ \\
Obese & $17(4.1)$ \\
Birth details & \\
Premature & \\
Exitization &
\end{tabular}

the following subtypes - predominantly inattentive subtype (13.62\%), predominantly hyperactive/ impulsive subtype (6.43\%) and combined inattention/hyperactivity (13.37\%). However, there was insufficient evidence to demonstrate a difference in ADHD subtypes with allergic rhinitis severity (Table 3.2).
Table 2. Allergic history of children with allergies aged 6 to 12 years $(n=415)$

\begin{tabular}{ll}
\hline & \multicolumn{1}{c}{$\begin{array}{c}\text { Frequency (\%); } \\
\text { Median (Range) }\end{array}$} \\
\hline Number of allergic comorbidities & $3(1-6)$ \\
Allergic rhinitis & $389(93.73)$ \\
Bronchial asthma & $376(90.6)$ \\
Atopic dermatitis & $206(49.64)$ \\
Allergic conjunctivitis & $28(6.75)$ \\
Drug allergy & $6(1.45)$ \\
Food allergy & $46(11.08)$ \\
Urticaria & $64(15.42)$
\end{tabular}

Table 3. Vanderbilt ADHD diagnostic parent rating subscales (VAPRS) of children with allergies aged 6 to 12 years $(n=415)$

\begin{tabular}{ll}
\hline & Frequency (\%) \\
\hline Predominantly inattentive subtype & $56(13.49)$ \\
$\begin{array}{l}\text { Predominantly hyperactive/impulsive } \\
\text { subtype }\end{array}$ & $25(6.02)$ \\
Combined inattention/hyperactivity & $54(13.01)$ \\
TOTAL & $135(32.5)$ \\
\hline
\end{tabular}

Of the 415 patients with allergies, 206 (50\%) were diagnosed with atopic dermatitis. Among these patients, 71 (34\%) had ADHD symptoms with the following subtypes - predominantly inattentive subtype (14.56\%), predominantly hyperactive/ impulsive subtype (4.85\%) and combined inattention/hyperactivity $(15.05 \%)$. There was insufficient evidence to demonstrate a difference in ADHD subtypes with atopic dermatitis severity (Table 3.3).

Likewise, the type of sensitization does not show sufficient evidence in demonstrating a significant difference among ADHD subtypes (Tables 3.4).

\section{DISCUSSION}

According to our knowledge, this was the first study in the Philippines to evaluate the prevalence and association of allergic diseases and ADHD symptoms.

This study demonstrated the prevalence of ADHD symptoms to be $32.5 \%$ in allergic school-aged patients with the following subtypes: predominantly inattentive subtype $=13.49 \%$, predominantly hyperactive $/$ impulsive subtype $=6.02 \%$ and 
Table 3.1 Vanderbilt ADHD diagnostic parent rating subscales (VAPRS) and asthma severity of children with asthma $(\mathrm{n}=376)$

\begin{tabular}{|c|c|c|c|c|c|}
\hline & $\begin{array}{c}\text { Total } \\
(\mathrm{n}=\mathbf{3 7 6})\end{array}$ & $\begin{array}{c}\text { Mild } \\
(\mathrm{n}=134)\end{array}$ & $\begin{array}{l}\text { Moderate } \\
(n=205)\end{array}$ & $\begin{array}{l}\text { Severe } \\
(\mathbf{n}=37)\end{array}$ & \multirow[t]{2}{*}{ p-value } \\
\hline & \multicolumn{4}{|c|}{ Frequency (\%) } & \\
\hline Predominantly inattentive subtype & $\begin{array}{l}51 \\
(13.56)\end{array}$ & $\begin{array}{l}20 \\
(14.92)\end{array}$ & $\begin{array}{l}27 \\
(13.2)\end{array}$ & $\begin{array}{l}4 \\
(10.81)\end{array}$ & $0.945 \dagger$ \\
\hline $\begin{array}{l}\text { Predominantly hyperactive/impul- } \\
\text { sive subtype }\end{array}$ & $\begin{array}{l}19 \\
(5.05)\end{array}$ & $\begin{array}{l}4 \\
(2.99)\end{array}$ & $\begin{array}{l}14 \\
(6.83)\end{array}$ & $\begin{array}{l}1 \\
(2.70)\end{array}$ & $0.262 \dagger$ \\
\hline Combined inattention/hyperactivity & $\begin{array}{l}49 \\
(13.03)\end{array}$ & $\begin{array}{l}14 \\
(10.45)\end{array}$ & $\begin{array}{l}25 \\
(12.2)\end{array}$ & $\begin{array}{l}10 \\
(27.03)\end{array}$ & $0.026 *$ \\
\hline Total & $\begin{array}{l}119 \\
(31.6)\end{array}$ & $\begin{array}{l}38 \\
(28.4)\end{array}$ & $\begin{array}{l}66 \\
(32.2)\end{array}$ & $\begin{array}{l}15 \\
(40.5)\end{array}$ & \\
\hline
\end{tabular}

Statistical tests used: * - Chi-squared test; $\dagger$ - Fisher's exact test

Table 3.2 Vanderbilt ADHD diagnostic parent rating subscales (VAPRS) and allergic rhinitis severity of children with allergic rhinitis $(n=389)$

\begin{tabular}{|c|c|c|c|c|c|c|}
\hline & $\begin{array}{c}\text { Total } \\
(n=389)\end{array}$ & $\begin{array}{c}\text { Mild } \\
\text { intermittent } \\
(n=139)\end{array}$ & $\begin{array}{l}\text { Moderate/ } \\
\text { Severe } \\
\text { intermittent } \\
(\mathbf{n}=\mathbf{2 1}) \\
\end{array}$ & $\begin{array}{c}\text { Mild } \\
\text { persistent } \\
(n=171)\end{array}$ & $\begin{array}{c}\text { Moderate/ } \\
\text { Severe } \\
\text { persistent } \\
(\mathbf{n}=\mathbf{5 2}) \\
\end{array}$ & p-value \\
\hline & \multicolumn{6}{|c|}{ Frequency (\%) } \\
\hline $\begin{array}{l}\text { Predominantly inatten- } \\
\text { tive subtype }\end{array}$ & $\begin{array}{l}53 \\
(13.62)\end{array}$ & $\begin{array}{l}18 \\
(12.9)\end{array}$ & 0 & $\begin{array}{l}28 \\
(16.37)\end{array}$ & $\begin{array}{l}7 \\
(13.46)\end{array}$ & $0.228^{\dagger}$ \\
\hline $\begin{array}{l}\text { Predominantly } \\
\text { hyperactive/impulsive } \\
\text { subtype }\end{array}$ & $\begin{array}{l}25 \\
(6.43)\end{array}$ & $\begin{array}{l}8 \\
(5.76)\end{array}$ & $\begin{array}{l}1 \\
(4.76)\end{array}$ & $\begin{array}{l}14 \\
(8.19)\end{array}$ & $\begin{array}{l}2 \\
(3.85)\end{array}$ & $0.811^{\dagger}$ \\
\hline $\begin{array}{l}\text { Combined } \\
\text { inattention/ } \\
\text { hyperactivity }\end{array}$ & $\begin{array}{l}52 \\
(13.37)\end{array}$ & $\begin{array}{l}16 \\
(11.51)\end{array}$ & $\begin{array}{l}4 \\
(19.05)\end{array}$ & $\begin{array}{l}23 \\
(13.45)\end{array}$ & $\begin{array}{l}9 \\
(17.31)\end{array}$ & $0.557^{\dagger}$ \\
\hline Total & $\begin{array}{l}130 \\
(33.4)\end{array}$ & $\begin{array}{l}42 \\
(33.4)\end{array}$ & $\begin{array}{l}5 \\
(23.8)\end{array}$ & $\begin{array}{l}65 \\
(38)\end{array}$ & $\begin{array}{l}18 \\
(34.6)\end{array}$ & \\
\hline
\end{tabular}

Statistical tests used: * - Chi-squared test; $\dagger$ - Fisher's exact test

Table 3.3 Vanderbilt ADHD diagnostic parent rating subscales (VAPRS) and atopic dermatitis severity of children with atopic dermatitis $(\mathrm{n}=206)$

\begin{tabular}{|c|c|c|c|c|c|}
\hline & $\begin{array}{c}\text { Total } \\
(\mathrm{n}=206) \\
\end{array}$ & $\begin{array}{c}\text { Mild } \\
(\mathrm{n}=144)\end{array}$ & $\begin{array}{c}\text { Moderate } \\
(n=56)\end{array}$ & $\begin{array}{l}\text { Severe } \\
(n=6)\end{array}$ & \multirow[t]{2}{*}{ p-value } \\
\hline & \multicolumn{4}{|c|}{ Frequency (\%) } & \\
\hline Predominantly inattentive subtype & $\begin{array}{l}30 \\
(14.56)\end{array}$ & $\begin{array}{l}24 \\
(16.67)\end{array}$ & $\begin{array}{l}6 \\
(10.71)\end{array}$ & 0 & 0.463 \\
\hline $\begin{array}{l}\text { Predominantly hyperactive/impul- } \\
\text { sive subtype }\end{array}$ & $\begin{array}{l}10 \\
(4.85)\end{array}$ & $\begin{array}{l}7 \\
(4.86)\end{array}$ & $\begin{array}{l}3 \\
(5.36)\end{array}$ & 0 & 1.000 \\
\hline Combined inattention/hyperactivity & $\begin{array}{l}31 \\
(15.05)\end{array}$ & $\begin{array}{l}20 \\
(13.89)\end{array}$ & $\begin{array}{l}9 \\
(16.07)\end{array}$ & $\begin{array}{l}2 \\
(33.33)\end{array}$ & 0.309 \\
\hline Total & $\begin{array}{l}71 \\
(34.4)\end{array}$ & $\begin{array}{l}51 \\
(35.4)\end{array}$ & $\begin{array}{l}18 \\
(32.1)\end{array}$ & $\begin{array}{l}2 \\
(33.33)\end{array}$ & \\
\hline
\end{tabular}

Statistical tests used: Fisher's exact test 
Table 3.4 Vanderbilt ADHD diagnostic parent rating subscales (VAPRS) and sensitization of children with allergies aged 6 to 12 years $(n=415)$

\begin{tabular}{lllll}
\hline & \multicolumn{1}{c}{$\begin{array}{c}\text { Total } \\
(\mathbf{n = 4 1 5 )}\end{array}$} & \multicolumn{1}{c}{$\begin{array}{c}\text { Monosensitized } \\
(\mathbf{n = 1 1 7 )}\end{array}$} & $\begin{array}{c}\text { Polysensitized } \\
(\mathbf{n = 2 9 8 )}\end{array}$ & \multirow{2}{*}{ P-value } \\
\cline { 2 - 4 } & \multicolumn{3}{c}{ Frequency (\%) } \\
\hline Predominantly inattentive subtype & 56 & 14 & 42 & $0.568^{*}$ \\
& $(13.49)$ & $(11.97)$ & $(14.09)$ & \multirow{2}{*}{$0.663^{*}$} \\
Predominantly hyperactive/impul- & 25 & 8 & 17 & \\
sive subtype & $(6.02)$ & $(6.84)$ & $(5.7)$ & $0.296^{*}$ \\
Combined inattention/hyperactivity & 54 & 12 & 42 & $(14.09)$ \\
& $(13.01)$ & $(10.26)$ & & \\
\hline
\end{tabular}

Statistical tests used: * - Chi-squared test; $\dagger$ - Fisher's exact test

combined inattention/hyperactivity subtype $=$ $13.01 \%$. Furthermore, an association between ADHD (combined inattention hyperactive subtype) symptoms and asthma severity was shown, but there was no association between allergic rhinitis and atopic dermatitis with ADHD symptoms.

The finding of the present study was consistent with a systematic review and meta-analysis which provided a strong evidence that individuals with asthma, eczema and allergic rhinitis have a $30 \%$ to $50 \%$ greater chance of developing ADHD.[3]

Similar to the worldwide trend, the most common allergic disease in this study was allergic rhinitis (94\%) and among these patients, 33\% had ADHD symptoms with the following subtypes - predominantly inattentive subtype (13.62\%), predominantly hyperactive/impulsive subtype $(6.43 \%)$ and combined inattention/hyperactivity (13.37\%). However, evidence was not sufficient to demonstrate a difference in ADHD subtypes with allergic rhinitis severity. Supporting this, a systematic study by Schmitt et al. did not show a relationship between allergic rhinitis and ADHD.[17] On the other hand, a systematic review and meta-analysis by Miyazaki et al. found that children with ADHD experienced $59 \%$ greater odds of having allergic rhinitis compared to children without ADHD; however, substantial evidence of heterogeneity and inconsistency were detected among the studies.[25]

In this study, 50\% were diagnosed with atopic dermatitis and among patients with atopic dermatitis, 71 (34\%) had ADHD symptoms with the following subtypes - predominantly inattentive subtype (14.56\%), predominantly hyperactive/ impulsive subtype $(4.85 \%)$ and combined inattention/hyperactivity (15.05\%). However, there was insufficient evidence to demonstrate a link between ADHD subtypes and atopic dermatitis severity. According to Romanos et al., children with atopic eczema and sleeping problems had a 2.5 -fold higher risk of being diagnosed with $A D H D$, whereas atopic eczema and ADHD were not significantly associated in children without sleep impairment. [26] Chang et al. reported that children who had been treated for atopic dermatitis in the past 12 months had higher attention problem and ADHD scores, which suggested that irritability and decreased concentration due to pruritus and scratching in atopic dermatitis might mimic ADHD symptoms. [4]

In this study, 91\% were diagnosed with asthma and among these asthmatics, 32\% had ADHD symptoms with the following subtypes - predominantly inattentive subtype (13.56\%), predominantly hyperactive/impulsive subtype $(5.05 \%)$ and combined inattention/hyperactivity $(13.03 \%)$. Results of this study revealed that only the combined inattention/hyperactivity subtype had a significant proportion of severe asthmatics compared to mild or moderate asthma. This was supported by Blackman et al.'s report which revealed a direct association between asthma severity and severity of behavioral problems, wherein ADHD symptoms were reported twice as often for asthmatics and three times as often for asthmatics with severe disease. [27] Holmberg et al.'s cohort analysis demonstrated a twofold increased risk of ADHD among children with severe asthma, not modified by asthma medication.[28] Two prospective studies supported a temporal relationship between asthma and ADHD. According to Chen et al., asthma in infancy and early childhood was an independent risk factor for ADHD development (hazard ratio $=1.31$ ). [29] In a population-based twin study, children with asthma aged 8-9 years had an almost twofold increased 
risk of having one or more symptom of hyperactivityimpulsivity and a more than twofold increased risk to have three symptoms or more of hyperactivityimpulsivity at age 13-14 years. [30]

In contrast, other studies found no significant relationship between asthma and ADHD. $[14,16]$ Evidence from individual studies, systematic reviews and meta-analyses was inconclusive with regards to whether a significant association exists between asthma and ADHD.[31] To fill this paucity of knowledge, Cortese et al. did a comprehensive systematic review and meta-analysis, wherein they rigorously confirmed a significant association between ADHD and asthma. For the sensitivity analysis in which asthma was more narrowly defined (ie, clinical diagnosis of asthma in the National Patient Register), the prevalence of asthma remained significantly higher in individuals with ADHD (19.7\%) than in those without asthma (12.3\%). The association between asthma and ADHD remained significant in both the crude and adjusted models.[31]

Taken together, current evidence suggests a strong association between allergy and ADHD and that children with allergy may be at increased risk of developing ADHD.[2] Several possible mechanisms and factors may elucidate the link between allergic diseases and neurobehavioral disorders. $[2,5,10]$

First, inflammation and immunologic dysregulation may play synergistic roles in increasing the risk of ADHD in allergic diseases.[2,29] Immaturity of the immune system during early life stages leads to exposure to high levels of proinflammatory cytokines among allergic children.[10] Allergic reactions result in hypersecretion of Immunoglobulin $E$ and inflammatory cytokines from T-helper type 2 (Th2) and T-helper type 17 (Th 17) cells, which penetrate the blood-brain barrier and activate neuroimmune mechanisms in the brain circuits associated with emotional and behavior control, such as the prefrontal cortex and anterior cingulate cortex. $[2,29,32]$ Functional and structural changes in these areas result in cognitive disturbances which resemble ADHD symptoms.[32]

Second, epigenetics and shared genetic factors may be underlying mechanisms in the etiology of both disorders. $[2,10]$ Both allergic diseases and ADHD are familial and highly heritable.[1,10] However, epigenetic mechanisms, which convey genomic adaptation to environmental factors, also play a role.[2]
The third plausible cause is neurotransmitter imbalance. ADHD is associated with neurotransmitter imbalance in the brain, including dopamine, norepinephrine and serotonin. Dysregulation of these neurotransmitters is also observed in allergic reactions, leading to the speculation that allergy could be one of the risk factors of ADHD. [10] Dopamine receptors, abundantly expressed on human $T$ cells, trigger the selective secretion of immunoregulatory cytokines, like Interleukin-10, and activates the Signal Transducer and Activator of Transcription 6 (STAT6), a transcription factor in Th2 cells of the immune system.[1] STAT6 gene, which is highly expressed in the central nervous system is closely related with allergic diseases and may be implicated in ADHD pathogenesis.[10] Gene polymorphism of dopamine receptor D5 (DRD5) is associated with ADHD behavior subtype, as well as in some part of Th17 cell differentiation, which is extensively involved in asthma development.[25]

The fourth key player in the link is gut microbiome dysbiosis, which plays an important role in allergic diseases and identical changes in host microbiome are increasingly being elucidated in ADHD patients.[2] The microbiota of ADHD patients exhibit a downregulation of Bifidobacterium and Lactobacillus, which produce gamma aminobutyric acid (GABA), as well as Streptococcus spp. and Enterococcus spp., which produce serotonin.[2] The microbiota of allergic children reveal decreased bacterial diversity with a lower prevalence of Bifidobacterium adolescentis, B. bifidum, Lactobacillus and Faecalibacterium prausnitzii among others. [33] Faecalibacterium may have antiinflammatory properties and their low levels may lead to higher expression of inflammatory factors that could contribute to ADHD pathogenesis. [34]

The fifth hypothesis was that both allergic diseases and ADHD share common comorbidities such as sleep problems. $[10,13,35]$ Sleep disturbance can lead to abnormal performance of brain circuits, including the prefrontal cortex, which in turn influences behavior and cognitive operations.[2] Sleep disruption associated with atopic mechanisms might contribute to ADHD symptoms, although there is evidence that the association remains significant even after controlling for loss of sleep.[31]

Another factor which may bridge the gap for understanding how allergy and neurodevelopmental disorders are interrelated is mitochondrial 
dysfunction. According to Chua etal., "malfunctioning mitochondria alter the bioenergetics and metabolic profile of the cell to favor systemic inflammation that plays a central role in the pathogenesis of chronic diseases, e.g., allergy and neurodevelopmental disorders."[2]

Based on Chua et al.'s narrative review, other common factors which may contribute to the development of both allergy and neurodevelopmental disorders include maternal depression and anxiety, gestational diabetes mellitus, maternal allergic status and environmental factors such as diet and environmental exposure to pollutants. [2] Since there is a lack of direct evidence of these factors linking both allergy and neurodevelopmental disorders, more longitudinal studies are warranted to study the association between the two disorders. [2]

Despite the suggested physiological plausibilities, the authors would like to emphasize that the results of the present study pertain only to an association between allergic diseases, in particular severe asthma and ADHD symptoms, under the assumption that these disorders were possibly coexisting conditions with shared pathophysiological mechanisms and not on the onset nor causative pathways between the two conditions.

From a clinical and public health perspective, a better understanding of the relationship between asthma severity and development of ADHD symptoms may lead to targeted early screening as well as improved preventive measures and quality of life for children with allergic disease who are at increased risk of developing ADHD.[1,20] Furthermore, since the existing guidelines for asthma did not mention ADHD, awareness might lead to prompt referral of patients with asthma and symptoms of ADHD to a neurodevelopmental and behavioral specialist, instead of these symptoms being attributed to an adjustment reaction to a chronic disorder or to the effect of pharmacological treatment for asthma. [31] Awareness of this association might reduce diagnostic delay, which is a vital public health issue for both asthma and ADHD. [31]

The strength of this study was that the status of allergic disease was physician-diagnosed and the skin prick tests, an objective measure of atopic sensitization, was performed by allergists. Hence, recruited subjects were truly atopic, ie, showed type
I (immediate type) sensitizations to environmental allergens. Also, elimination of potential confounding factors in terms of neurocognitive and behavioral condition, family environment (eg, parents' mental health) and other potential coexisting mental diseases (eg, ADHD, anxiety disorder, major depressive disorder, autism spectrum disorder) was done.

This study should be interpreted in the context of its limitations. First, ADHD symptoms were assessed using parent-report questionnaires, which was not sufficient alone to make a diagnosis of ADHD. However, since VADPRS was a well-established tool for ADHD evaluation and was validated in Filipinos, its use in this study was unlikely to lead to substantial under- or over-reporting of disease severity and prevalence. Second, since this was a cross-sectional survey, causal relationships could not be established. Yet, cross-sectional studies with a large sample size were helpful to identify risk factors of health-related status and were widely used in epidemiological studies.[36] Hence, a longitudinal follow-up of the subjects who screened positive and were assessed by a developmental specialist is needed to have a better understanding of the causality between ADHD and allergy. Another recommendation is to identify who amongst the ADHD patients will be treated with medications for ADHD and if these medications alter the allergenicity of these patients. Lastly, a prospective cohort study starting before the onset of allergic diseases will be needed to identify the trajectory and cause and effect relationship of allergic diseases and associated psychological problems. Such prospective studies will be more complicated to conduct, but cross-sectional studies such as this current one can still make important contributions in suggesting the likelihood of an association.[10]

In conclusion, this study showed an association between severe asthma and ADHD (combined inattention hyperactive subtype) symptoms, but no association between allergic rhinitis and atopic dermatitis with ADHD symptoms. Hence, children with allergic diseases, especially severe asthma, should be screened and closely followed up since they are at risk of developing ADHD symptoms. Awareness of the association between these allergies and ADHD will prompt early intervention and treatment in the presence of early signs and symptoms.[17] 


\section{REFERENCES}

1. Suwan P, Akaramethathip D, Noipayak P. Association between allergic sensitization and attention deficit hyperactivity disorder (ADHD). Asian Pac J Allergy Immunol. 2011 Mar;29(1):57-65.

2. Chua RXY, Tay MY, Ooi DSQ, Siah KTH, Tham EH, Shek $L P-C$, et al. Understanding the link between allergy and neurodevelopmental disorders: A current review of factors and mechanisms. Front Neurol [Internet]. 2021 Feb 15;11:115. Available from: http://dx.doi.org/10.3389/ fneur.2020.603571

3. Schans J van der, Çiçek R, de Vries TW, Hak E, Hoekstra PJ. Association of atopic diseases and attention-deficit/ hyperactivity disorder: A systematic review and meta-analyses. Neuroscience \& Biobehavioral Reviews [Internet]. 2017 Mar;74:139-48. Available from: http://dx.doi. org/10.1016/i.neubiorev.2017.01.011

4. Chang HY, Seo J-H, Kim HY, Kwon J-W, Kim B-J, Kim HB, et al. Allergic diseases in preschoolers are associated with psychological and behavioural problems. Allergy Asthma Immunol Res [Internet]. 2013;5(5):315. Available from: http://dx.doi.org/10.4168/aair.2013.5.5.315

5. Chen M-H, Su T-P, Chen Y-S, Hsu J-W, Huang K-L, Chang $\mathrm{W}-\mathrm{H}$, et al. Attention deficit hyperactivity disorder, tic disorder, and allergy: is there a link? A nationwide populationbased study. Journal of Child Psychology and Psychiatry [Internet]. 2012 Nov 12;54(5):545-51. Available from: http://dx.doi.org/10.1111/jcpp. 12018

6. Strom MA, Fishbein AB, Paller AS, Silverberg Jl. Association between atopic dermatitis and attention deficit hyperactivity disorder in U.S. children and adults. $\mathrm{Br} J$ Dermatol [Internet]. 2016 Aug 28;175(5):920-9. Available from: http://dx.doi.org/10.1111/bjd.14697

7. Genuneit J, Braig S, Brandt S, Wabitsch M, Florath I, Brenner $\mathrm{H}$, et al. Infant atopic eczema and subsequent attention-deficit/hyperactivity disorder - A prospective birth cohort study. Pediatr Allergy Immunol [Internet]. 2013 Dec 1;25(1):516. Available from: http://dx.doi.org/10.1111/pai.12152

8. Romanos M, Gerlach M, Warnke A, Schmitt J. Association of attention-deficit/hyperactivity disorder and atopic eczema modified by sleep disturbance in a large population-based sample. Journal of Epidemiology \& Community Health [Internet]. 2009 Aug 19;64(3):269-73. Available from: http://dx.doi.org/10.1136/jech.2009.093534

9. Melli LCFL, do Carmo-Rodrigues MS, Araújo-Filho HB, Solé $D$, de Morais MB. Intestinal microbiota and allergic diseases: A systematic review. Allergologia et Immunopathologia [Internet]. 2016 Mar;44(2):177-88. Available from: http://dx.doi.org/10.1016/i.aller.2015.01.013

10. Checa-Ros A, Jeréz-Calero A, Molina-Carballo A, Campoy C, Muñoz-Hoyos A. Current evidence on the role of the gut microbiome in ADHD pathophysiology and therapeutic implications. Nutrients [Internet]. 2021 Jan 16;13(1):249. Available from: http://dx.doi.org/10.3390/nu 13010249

11. Hak E, de Vries TW, Hoekstra PJ, Jick SS. Association of childhood attention-deficit/hyperactivity disorder with atopic diseases and skin infections? A matched case-control study using the General Practice Research Database. Annals of Allergy, Asthma \& Immunology [Internet]. 2013 Aug; $111(2)$ : 102-106.e2. Available from: http://dx.doi. org/10.1016/i.anai.2013.05.023

12. Lin Y-T, Chen Y-C, Gau SS-F, Yeh T-H, Fan H-Y, Hwang Y-Y, et al. Associations between allergic diseases and attention deficit hyperactivity/oppositional defiant disorders in children. Pediatr Res [Internet]. 2016 Jun 2;80(4):480-5. Available from: http://dx.doi.org/10.1038/pr.2016.111

13. Yang C-F, Yang C-C, Wang I-J. Association between allergic diseases, allergic sensitization and attention-deficit/ hyperactivity disorder in children: A large-scale, population-based study. Journal of the Chinese Medical Association [Internet]. 2018 Mar;81(3):277-83. Available from: http://dx.doi.org/10.1016/i.jcma.2017.07.016

14. Yang M-T, Lee W-T, Liang J-S, Lin Y-J, Fu W-M, Chen C-C. Hyperactivity and impulsivity in children with untreated allergic rhinitis: corroborated by rating scale and continuous performance test. Pediatrics \& Neonatology [Internet]. 2014 Jun;55(3):168-74. Available from: http://dx.doi. org/10.1016/i.pedneo.2013.09.003

15. Jiang $X$, Shen $C$, Dai $Y$, Jiang F, Li S, Shen X, et al. Early food allergy and respiratory allergy symptoms and attention-deficit/hyperactivity disorder in Chinese children: A cross-sectional study. Pediatr Allergy Immunol [Internet]. 2018 Apr 15;29(4):402-9. Available from: http://dx.doi. org/10.1111/pai.12888

16. Brawley A, Silverman B, Kearney S, Guanzon D, Owens $M$, Bennett $H$, et al. Allergic rhinitis in children with attention-deficit/hyperactivity disorder. Annals of Allergy, Asthma \& Immunology [Internet]. 2004 Jun;92(6):6637. Available from: http://dx.doi.org/10.1016/ S1081-1206(10)61434-2

17. Biederman J, Milberger S, Faraone SV, Guite J, Warburton R. Associations between childhood asthma and ADHD: Issues of psychiatric comorbidity and familiality. Journal of the American Academy of Child \& Adolescent Psychiatry [Internet]. 1994 Jul;33(6):842-8. Available from: http:// dx.doi.org/10.1097/00004583-199407000-00010

18. Gaitens T, Kaplan BJ, Freigang B. Absence of an association between lgE-mediated atopic responsiveness and ADHD symptomatology. J Child Psychol Psychiatry. 1998 Mar;39(3):427-31.

19. McGee R, Stanton WR, Sears MR. Allergic disorders and attention deficit disorder in children. J Abnorm Child Psychol [Internet]. 1993 Feb;21(1):79-88. Available from: http://dx.doi.org/10.1007/BF00910490

20. Schmitt J, Buske-Kirschbaum A, Roessner V. Is atopic disease a risk factor for attention-deficit/hyperactivity disorder? A systematic review. Allergy [Internet]. 2010 Aug 17;65(12):1506-24. Available from: http://dx.doi. org/10.1111/j.1398-9995.2010.02449.x

21. Global Initiative for Asthma. Global strategy for asthma management and prevention, 2018 [Internet]. [updated 2021 ; cited 2018 May 2]. Available from: http://www. ginasthma.org/.

22. Scadding GK, Durham SR, Mirakian R, Jones NS, Leech SC, Farooque $S$, et al. BSACl guidelines for the management of allergic and non-allergic rhinitis. Clinical \& Experimental Allergy [Internet]. 2007 Dec 7;38(1): 19-42. Available from: http://dx.doi.org/10.1111/i.1365-2222.2007.02888.x

23. Lewis-Jones S, Mugglestone MA. Management of atopic eczema in children aged up to 12 years: summary of NICE guidance. BM [Internet]. 2007 Dec 13;335(7632):12634. Available from: http://dx.doi.org/10.1136/ bmj.39405.503773.AD

24. Kliegman R, Kliegman R, Stanton B, St Geme JW III, Schor NF, Behrman RE, Nelson W, et al. Nelson Textbook of Pediatrics. 20 th ed. Philadelphia, PA: Elsevier, 2016. 
25. Cabral MDI, Liu S, Soares N. Attention-deficit/hyperactivity disorder: diagnostic criteria, epidemiology, risk factors and evaluation in youth. Transl Pediatr [Internet]. 2020 Feb;9(S1):S104-13. Available from: http://dx.doi. org/10.21037/tp.2019.09.08

26. Diaz, LY, Pacifico, R, Sosa MG. Validation of the Filipino translation of the Vanderbilt ADHD Parent Rating Scale in the diagnosis of ADHD in Filipino children. [Unpublished]. Department of Pediatrics - De La Salle Health Sciences Institute; June 2014.

27. NICHQ Vanderbilt Assessment Scales [Internet]. 2002 [cited 2018 July 1]. Available from: https://www.nichq. org/sites/default/files/resource-file/NICHQ-VanderbiltAssessment-Scales.pdf

28. Miyazaki C, Koyama M, Ota E, Swa T, Mlunde LB, Amiya RM, et al. Allergic diseases in children with attention deficit hyperactivity disorder: a systematic review and meta-analysis. BMC Psychiatry [Internet]. 2017 Mar $31 ; 17(1)$. Available from: http://dx.doi.org/10.1186/ s12888-017-1281-7

29. Blackman JA, Gurka M. Developmental and behavioral comorbidities of asthma in children. Journal of Developmental \& Behavioral Pediatrics [Internet]. 2007 Apr;28(2):929. Available from: http://dx.doi.org/10.1097/01. DBP.0000267557.80834.e5

30. Holmberg K, Lundholm C, Anckarsäter H, Larsson H, Almqvist $C$. Impact of asthma medication and familial factors on the association between childhood asthma and attention-deficit/hyperactivity disorder: a combined twin- and register-based study. Clin Exp Allergy [Internet]. 2015 Apr 16;45(5):964-73. Available from: http://dx.doi. org/10.1111/cea. 12529

31. Chen M-H, Su T-P, Chen Y-S, Hsu J-W, Huang K-L, Chang $\mathrm{W}-\mathrm{H}$, et al. Asthma and attention-deficit/hyperactivity disorder: a nationwide population-based prospective cohort study. J Child Psychol Psychiatr [Internet]. 2013 Jun 3;54(1 1):1208-14. Available from: http://dx.doi. org/10.1111/icpp. 12087

32. Mogensen $N$, Larsson $H$, Lundholm C, Almqvist C. Association between childhood asthma and ADHD symptoms in adolescence - a prospective population-based twin study. Allergy
[Internet]. 2011 May $21 ; 66(9): 1224-30$. Available from: http://dx.doi.org/10.1111/j.1398-9995.2011.02648.x

33. Cortese S, Sun S, Zhang J, Sharma E, Chang Z, Kuja-Halkola $R$, et al. Association between attention deficit hyperactivity disorder and asthma: a systematic review and meta-analysis and a Swedish population-based study. The Lancet Psychiatry [Internet]. 2018 Sep;5(9):717-26. Available from: http://dx.doi.org/10.1016/S2215-0366(18)30224-4

34. Wang L-J, Yu Y-H, Fu M-L, Yeh W-T, Hsu J-L, Yang Y-H, et al. Attention deficit-hyperactivity disorder is associated with allergic symptoms and low levels of hemoglobin and serotonin. Sci Rep [Internet]. 2018 Jul 6;8(1). Available from: http://dx.doi.org/10.1038/s41598-018-28702-5

35. Tsai J-D, Chang S-N, Mou C-H, Sung F-C, Lue K-H. Association between atopic diseases and attention-deficit/ hyperactivity disorder in childhood: a population-based case-control study. Annals of Epidemiology [Internet]. 2013 Apr;23(4):185-8. Available from: http://dx.doi. org/10.1016/i.annepidem.2012.12.015

36. Jiang X, Shen C, Hu Y, Li F. Reply to Khosravi Shadmani F. et al. Pediatr Allergy Immunol [Internet]. 2018 Jun 22;29(5):572-572. Available from: http://dx.doi. org/10.1111/pai. 12906

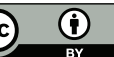

Open Access This article is licensed under a Creative Commons Attribution 4.0 International License, which permits use, sharing, adaptation, distribution and reproduction in any medium or format, as long as you give appropriate credit to the original author(s) and the source, provide a link to the Creative Commons license, and indicate if changes were made. The images or other third party material in this article are included in the article's Creative Commons license, unless indicated otherwise in a credit line to the material. If material is not included in the article's Creative Commons license and your intended use is not permitted by statutory regulation or exceeds the permitted use, you will need to obtain permission directly from the copyright holder. To view a copy of this license, visit http://creativecommons.org/licenses/by/4.0/.

\section{APPENDIX A}

\section{Vanderbilt ADHD diagnostic parent rating scale (VADPRS) of children with allergies aged 6 to 12 years $(n=415)$}

\begin{tabular}{lcccc}
\hline & $\begin{array}{c}\mathbf{0} \\
\text { (Never) }\end{array}$ & $\begin{array}{c}\mathbf{1} \\
\text { (Occasionally) }\end{array}$ & $\begin{array}{c}\mathbf{2} \\
\text { (Often) }\end{array}$ & $\begin{array}{c}\mathbf{3} \\
\text { (Very Often) }\end{array}$ \\
\cline { 2 - 5 } & \multicolumn{2}{c}{ Frequency (\%) } \\
\hline 1. Does not pay attention to details or makes & 36 & 189 & 145 & 45 \\
careless mistakes with, for example, homework & $(8.67)$ & $(45.54)$ & $(34.94)$ & $(10.84)$ \\
2. Has difficulty keeping attention to what needs & 78 & 183 & 132 & 22 \\
to be done & $(18.8)$ & $(44.1)$ & $(31.81)$ & $(5.3)$ \\
3. Does not seem to listen when spoken to & 100 & 183 & 105 & 27 \\
directly & $(24.1)$ & $(44.1)$ & $(25.3)$ & $(6.51)$ \\
4. Does not follow through when given directions & 112 & 182 & 100 & 21 \\
and fails to finish activities (not due to refusal & $(26.99)$ & $(43.86)$ & $(24.1)$ & $(5.06)$
\end{tabular}




\begin{tabular}{|c|c|c|c|c|}
\hline & $\begin{array}{c}0 \\
\text { (Never) }\end{array}$ & $\begin{array}{c}1 \\
\text { (Occasionally) }\end{array}$ & $\begin{array}{c}2 \\
\text { (Often) }\end{array}$ & $\begin{array}{c}3 \\
\text { (Very Often) }\end{array}$ \\
\hline & \multicolumn{4}{|c|}{ Frequency (\%) } \\
\hline 5. Has difficulty organizing tasks and activities & $\begin{array}{c}76 \\
(18.31)\end{array}$ & $\begin{array}{c}225 \\
(54.22)\end{array}$ & $\begin{array}{c}91 \\
(21.93)\end{array}$ & $\begin{array}{c}23 \\
(5.54)\end{array}$ \\
\hline $\begin{array}{l}\text { 6. Avoids, dislikes, or does not want to start } \\
\text { tasks that require ongoing mental effort }\end{array}$ & $\begin{array}{c}90 \\
(21.69)\end{array}$ & $\begin{array}{c}204 \\
(49.16)\end{array}$ & $\begin{array}{c}109 \\
(26.27)\end{array}$ & $\begin{array}{c}12 \\
(2.89)\end{array}$ \\
\hline $\begin{array}{l}\text { 7. Loses things necessary for tasks or activities } \\
\text { (toys, assignments, pencils, or books) }\end{array}$ & $\begin{array}{c}80 \\
(19.28)\end{array}$ & $\begin{array}{c}212 \\
(51.08)\end{array}$ & $\begin{array}{c}88 \\
(21.2)\end{array}$ & $\begin{array}{c}35 \\
(8.43)\end{array}$ \\
\hline 8. Is easily distracted by noises or other stimuli & $\begin{array}{c}57 \\
(13.73)\end{array}$ & $\begin{array}{c}181 \\
(43.61)\end{array}$ & $\begin{array}{c}123 \\
(29.64)\end{array}$ & $\begin{array}{c}54 \\
(13.01)\end{array}$ \\
\hline 9. Is forgetful in daily activities & $\begin{array}{c}72 \\
(17.35)\end{array}$ & $\begin{array}{c}218 \\
(52.53)\end{array}$ & $\begin{array}{c}108 \\
(26.02)\end{array}$ & $\begin{array}{c}17 \\
(4.1)\end{array}$ \\
\hline 10. Fidgets with hands or feet or squirms in seat & $\begin{array}{c}89 \\
(21.45)\end{array}$ & $\begin{array}{c}181 \\
(43.61)\end{array}$ & $\begin{array}{c}91 \\
(21.93)\end{array}$ & $\begin{array}{c}54 \\
(13.01)\end{array}$ \\
\hline $\begin{array}{l}\text { 11. Leaves the seat when remaining seated is } \\
\text { expected }\end{array}$ & $\begin{array}{c}135 \\
(32.53)\end{array}$ & $\begin{array}{c}158 \\
(38.07)\end{array}$ & $\begin{array}{c}88 \\
(21.2)\end{array}$ & $\begin{array}{c}34 \\
(8.19)\end{array}$ \\
\hline $\begin{array}{l}\text { 12. Runs about or climbs too much when remain- } \\
\text { ing seated is expected }\end{array}$ & $\begin{array}{c}176 \\
(42.41)\end{array}$ & $\begin{array}{c}123 \\
(29.64)\end{array}$ & $\begin{array}{c}78 \\
(18.8)\end{array}$ & $\begin{array}{c}38 \\
(9.16)\end{array}$ \\
\hline $\begin{array}{l}\text { 13. Has difficulty playing or beginning quiet } \\
\text { play activities }\end{array}$ & $\begin{array}{c}174 \\
(41.93)\end{array}$ & $\begin{array}{c}161 \\
(38.8)\end{array}$ & $\begin{array}{c}63 \\
(15.18)\end{array}$ & $\begin{array}{c}17 \\
(4.1)\end{array}$ \\
\hline $\begin{array}{l}\text { 14. Is "on the go" or often acts as if "driven by } \\
\text { a motor" }\end{array}$ & $\begin{array}{c}181 \\
(43.61)\end{array}$ & $\begin{array}{c}150 \\
(36.14)\end{array}$ & $\begin{array}{c}66 \\
(15.9)\end{array}$ & $\begin{array}{c}18 \\
(4.34)\end{array}$ \\
\hline 15. Talks too much & $\begin{array}{c}88 \\
(21.2)\end{array}$ & $\begin{array}{c}162 \\
(39.04)\end{array}$ & $\begin{array}{c}102 \\
(24.58)\end{array}$ & $\begin{array}{c}63 \\
(15.18)\end{array}$ \\
\hline $\begin{array}{l}\text { 16. Blurts out answers before questions have } \\
\text { been completed }\end{array}$ & $\begin{array}{c}126 \\
(30.36)\end{array}$ & $\begin{array}{c}172 \\
(41.45)\end{array}$ & $\begin{array}{c}90 \\
(21.69)\end{array}$ & $\begin{array}{c}27 \\
(6.51)\end{array}$ \\
\hline 17. Has difficulty waiting his or her turn & $\begin{array}{c}104 \\
(25.06)\end{array}$ & $\begin{array}{c}186 \\
(44.82)\end{array}$ & $\begin{array}{c}101 \\
(24.34)\end{array}$ & $\begin{array}{c}24 \\
(5.78)\end{array}$ \\
\hline $\begin{array}{l}\text { 18. Interrupts or intrudes in on others' conversa- } \\
\text { tions and/or activities }\end{array}$ & $\begin{array}{c}128 \\
(30.84)\end{array}$ & $\begin{array}{c}177 \\
(42.65)\end{array}$ & $\begin{array}{c}87 \\
(20.96)\end{array}$ & $\begin{array}{c}23 \\
(5.54)\end{array}$ \\
\hline 19. Argues with adults & $\begin{array}{c}196 \\
(47.23)\end{array}$ & $\begin{array}{c}121 \\
(29.16)\end{array}$ & $\begin{array}{c}69 \\
(16.63)\end{array}$ & $\begin{array}{c}29 \\
(6.99)\end{array}$ \\
\hline 20. Loses temper & $\begin{array}{c}158 \\
(38.07)\end{array}$ & $\begin{array}{c}150 \\
(36.14)\end{array}$ & $\begin{array}{c}81 \\
(19.52)\end{array}$ & $\begin{array}{c}26 \\
(6.27)\end{array}$ \\
\hline $\begin{array}{l}\text { 21. Actively defies or refuses to go along with } \\
\text { adults' requests or rules }\end{array}$ & $\begin{array}{c}149 \\
(35.9)\end{array}$ & $\begin{array}{c}176 \\
(42.41)\end{array}$ & $\begin{array}{c}74 \\
(17.83)\end{array}$ & $\begin{array}{c}16 \\
(3.86)\end{array}$ \\
\hline 22. Deliberately annoys people & $\begin{array}{c}154 \\
(37.11)\end{array}$ & $\begin{array}{c}164 \\
(39.52)\end{array}$ & $\begin{array}{c}72 \\
(17.35)\end{array}$ & $\begin{array}{c}25 \\
(6.02)\end{array}$ \\
\hline $\begin{array}{l}\text { 23. Blames others for his or her mistakes or } \\
\text { misbehaviors }\end{array}$ & $\begin{array}{c}200 \\
(48.19)\end{array}$ & $\begin{array}{c}154 \\
(37.11)\end{array}$ & $\begin{array}{c}42 \\
(10.12)\end{array}$ & $\begin{array}{c}19 \\
(4.58)\end{array}$ \\
\hline 24. Is touchy or easily annoyed by others & $\begin{array}{c}156 \\
(37.59)\end{array}$ & $\begin{array}{c}174 \\
(41.93)\end{array}$ & $\begin{array}{c}50 \\
(12.05)\end{array}$ & $\begin{array}{c}35 \\
(8.43)\end{array}$ \\
\hline 25. Is angry or resentful & $\begin{array}{c}240 \\
(57.83)\end{array}$ & $\begin{array}{c}128 \\
(30.84)\end{array}$ & $\begin{array}{c}32 \\
(7.71)\end{array}$ & $\begin{array}{c}15 \\
(3.61)\end{array}$ \\
\hline 26. Is spiteful and wants to get even & $\begin{array}{c}259 \\
(62.41)\end{array}$ & $\begin{array}{c}109 \\
(26.27)\end{array}$ & $\begin{array}{c}35 \\
(8.43)\end{array}$ & $\begin{array}{c}12 \\
(2.89)\end{array}$ \\
\hline 27. Bullies, threatens, or intimidates others & $\begin{array}{c}281 \\
(67.71)\end{array}$ & $\begin{array}{c}109 \\
(26.27)\end{array}$ & $\begin{array}{c}19 \\
(4.58)\end{array}$ & $\begin{array}{l}6 \\
(1.45)\end{array}$ \\
\hline 28. Starts physical fights & $\begin{array}{c}335 \\
(80.72)\end{array}$ & $\begin{array}{c}56 \\
(13.49)\end{array}$ & $\begin{array}{c}16 \\
(3.86)\end{array}$ & $\begin{array}{c}8 \\
(1.93)\end{array}$ \\
\hline $\begin{array}{l}\text { 29. Lies to get out of trouble or to avoid obliga- } \\
\text { tions (ie, "cons" others) }\end{array}$ & $\begin{array}{c}219 \\
(52.77)\end{array}$ & $\begin{array}{c}158 \\
(38.07)\end{array}$ & $\begin{array}{c}29 \\
(6.99)\end{array}$ & $\begin{array}{c}9 \\
(2.17)\end{array}$ \\
\hline
\end{tabular}




\begin{tabular}{|c|c|c|c|c|}
\hline & $\begin{array}{c}0 \\
\text { (Never) }\end{array}$ & $\begin{array}{c}1 \\
\text { (Occasionally) }\end{array}$ & $\begin{array}{c}2 \\
\text { (Often) }\end{array}$ & $\begin{array}{c}3 \\
\text { (Very Often) }\end{array}$ \\
\hline & \multicolumn{4}{|c|}{ Frequency (\%) } \\
\hline $\begin{array}{l}\text { 30. Is truant from school (skips school) without } \\
\text { permission }\end{array}$ & $\begin{array}{c}311 \\
(74.94)\end{array}$ & $\begin{array}{c}78 \\
(18.8)\end{array}$ & $\begin{array}{c}19 \\
(4.58)\end{array}$ & $\begin{array}{c}7 \\
(1.69)\end{array}$ \\
\hline 31. Is physically cruel to people & $\begin{array}{c}333 \\
(80.24)\end{array}$ & $\begin{array}{c}65 \\
(15.66)\end{array}$ & $\begin{array}{c}9 \\
(2.17)\end{array}$ & $\begin{array}{c}8 \\
(1.93)\end{array}$ \\
\hline 32. Has stolen things that have value & $\begin{array}{c}348 \\
(83.86)\end{array}$ & $\begin{array}{c}56 \\
(13.49)\end{array}$ & $\begin{array}{c}4 \\
(0.96)\end{array}$ & $\begin{array}{c}7 \\
(1.69)\end{array}$ \\
\hline 33. Deliberately destroys others' property & $\begin{array}{c}344 \\
(82.89)\end{array}$ & $\begin{array}{l}60 \\
(14.46)\end{array}$ & $\begin{array}{c}9 \\
(2.17)\end{array}$ & $\begin{array}{c}2 \\
(0.48)\end{array}$ \\
\hline $\begin{array}{l}\text { 34. Has used a weapon that can cause serious } \\
\text { harm (bat, knife, brick, gun) }\end{array}$ & $\begin{array}{c}361 \\
(86.99)\end{array}$ & $\begin{array}{c}41 \\
(9.88)\end{array}$ & $\begin{array}{c}9 \\
(2.17)\end{array}$ & $\begin{array}{c}4 \\
(0.96)\end{array}$ \\
\hline 35. Is physically cruel to animals & $\begin{array}{c}352 \\
(84.82)\end{array}$ & $\begin{array}{c}52 \\
(12.53)\end{array}$ & $\begin{array}{c}8 \\
(1.93)\end{array}$ & $\begin{array}{c}3 \\
(0.72)\end{array}$ \\
\hline 36. Has deliberately set fire to cause damage & $\begin{array}{c}368 \\
(88.67)\end{array}$ & $\begin{array}{c}38 \\
(9.16)\end{array}$ & $\begin{array}{l}6 \\
(1.45)\end{array}$ & $\begin{array}{c}3 \\
(0.72)\end{array}$ \\
\hline $\begin{array}{l}\text { 37. Has broken into someone else's home, } \\
\text { business, or car }\end{array}$ & $\begin{array}{c}362 \\
(87.23)\end{array}$ & $\begin{array}{c}36 \\
(8.67)\end{array}$ & $\begin{array}{c}10 \\
(2.41)\end{array}$ & $\begin{array}{c}7 \\
(1.69)\end{array}$ \\
\hline 38. Has stayed out at night without permission & $\begin{array}{c}292 \\
(70.36)\end{array}$ & $\begin{array}{c}93 \\
(22.41)\end{array}$ & $\begin{array}{l}17 \\
(4.1)\end{array}$ & $\begin{array}{c}13 \\
(3.13)\end{array}$ \\
\hline 39. Has run away from home overnight & $\begin{array}{c}354 \\
(85.3)\end{array}$ & $\begin{array}{c}43 \\
(10.36)\end{array}$ & $\begin{array}{c}10 \\
(2.41)\end{array}$ & $\begin{array}{c}8 \\
(1.93)\end{array}$ \\
\hline 40. Has forced someone into sexual activity & $\begin{array}{c}338 \\
(81.45)\end{array}$ & $\begin{array}{c}60 \\
(14.46)\end{array}$ & $\begin{array}{c}13 \\
(3.13)\end{array}$ & $\begin{array}{c}4 \\
(0.96)\end{array}$ \\
\hline 41. Is fearful, anxious or worried & $\begin{array}{c}171 \\
(41.2)\end{array}$ & $\begin{array}{c}170 \\
(40.96)\end{array}$ & $\begin{array}{c}46 \\
(11.08)\end{array}$ & $\begin{array}{c}28 \\
(6.75)\end{array}$ \\
\hline $\begin{array}{l}\text { 42. Is afraid to try new things for fear of making } \\
\text { mistakes }\end{array}$ & $\begin{array}{c}135 \\
(32.53)\end{array}$ & $\begin{array}{c}202 \\
(48.67)\end{array}$ & $\begin{array}{c}60 \\
(14.46)\end{array}$ & $\begin{array}{c}18 \\
(4.34)\end{array}$ \\
\hline 43. Feels worthless or inferior & $\begin{array}{c}251 \\
(60.48)\end{array}$ & $\begin{array}{c}102 \\
(24.58)\end{array}$ & $\begin{array}{c}48 \\
(11.57)\end{array}$ & $\begin{array}{c}14 \\
(3.37)\end{array}$ \\
\hline 44. Blames self for problems, feels guilty & $\begin{array}{c}219 \\
(52.77)\end{array}$ & $\begin{array}{c}149 \\
(35.9)\end{array}$ & $\begin{array}{c}27 \\
(6.51)\end{array}$ & $\begin{array}{c}20 \\
(4.82)\end{array}$ \\
\hline $\begin{array}{l}\text { 45. Feels lonely, unwanted, or unloved; com- } \\
\text { plains that "no one loves him or her" }\end{array}$ & $\begin{array}{c}258 \\
(62.17)\end{array}$ & $\begin{array}{c}95 \\
(22.89)\end{array}$ & $\begin{array}{c}42 \\
(10.12)\end{array}$ & $\begin{array}{c}20 \\
(4.82)\end{array}$ \\
\hline 46. Is sad, unhappy, or depressed & $\begin{array}{c}244 \\
(58.8)\end{array}$ & $\begin{array}{c}126 \\
(30.36)\end{array}$ & $\begin{array}{l}39 \\
(9.4)\end{array}$ & $\begin{array}{l}6 \\
(1.45)\end{array}$ \\
\hline 47. Is self-conscious or easily embarrassed & $\begin{array}{c}231 \\
(55.66)\end{array}$ & $\begin{array}{c}136 \\
(32.77)\end{array}$ & $\begin{array}{c}30 \\
(7.23)\end{array}$ & $\begin{array}{c}18 \\
(4.34)\end{array}$ \\
\hline
\end{tabular}

Response to performance questions of parents of children with allergies aged 6 to 12 years $(n=415)$

\begin{tabular}{lccccc}
\hline & $\begin{array}{c}\mathbf{1} \\
\text { (Excellent) }\end{array}$ & $\begin{array}{c}\mathbf{2} \\
\text { (Above } \\
\text { Average) }\end{array}$ & $\begin{array}{c}\mathbf{3} \\
\text { (Average) }\end{array}$ & $\begin{array}{c}\mathbf{4} \\
\text { (Somewhat } \\
\text { average) }\end{array}$ & $\begin{array}{c}\mathbf{5} \\
\text { (Problematic) }\end{array}$ \\
\cline { 2 - 6 } & \multicolumn{5}{c}{ Frequency (\%) } \\
\hline Academic Performance & $61(14.7)$ & $118(28.43)$ & $159(38.31)$ & $70(16.87)$ & $70(16.87)$ \\
Reading & $32(7.71)$ & $89(21.45)$ & $182(43.86)$ & $104(25.06)$ & $104(25.06)$ \\
Mathematics & $38(9.16)$ & $87(20.96)$ & $191(46.02)$ & $94(22.65)$ & $94(22.65)$ \\
Written expression & & &
\end{tabular}




\begin{tabular}{lccccc}
\hline & $\begin{array}{c}\mathbf{1} \\
\text { (Excellent) }\end{array}$ & $\begin{array}{c}\mathbf{2} \\
\text { (Above } \\
\text { Average) }\end{array}$ & $\begin{array}{c}\mathbf{3} \\
\text { (Average) }\end{array}$ & $\begin{array}{c}\mathbf{4} \\
\text { (Somewhat } \\
\text { average) }\end{array}$ & $\begin{array}{c}\mathbf{5} \\
\text { (Problematic) }\end{array}$ \\
\cline { 2 - 6 } & \multicolumn{5}{c}{ Frequency (\%) } \\
\hline Classroom behavior & $46(11.08)$ & $114(27.47)$ & $223(53.73)$ & $29(6.99)$ & $29(6.99)$ \\
Relationship with peers & $54(13.01)$ & $107(25.78)$ & $199(47.95)$ & $51(12.29)$ & $51(12.29)$ \\
Following directions/rules & $50(12.05)$ & $58(13.98)$ & $176(42.41)$ & $80(19.28)$ & $51(12.29)$ \\
Disrupting class & $73(17.59)$ & $99(23.86)$ & $163(39.28)$ & $73(17.59)$ & $73(17.59)$ \\
Assignment completion & $44(10.6)$ & $78(18.8)$ & $221(53.25)$ & $65(15.66)$ & $65(15.66)$ \\
Organizational skills & & & & & \\
\hline
\end{tabular}

